Комунальний вищий навчальний заклад

“Житомирський базовий фармацевтичний коледж” Житомирської обласної ради

\title{
СУЧАСНІ МАТЕМАТИЧНІ МОДЕЛІ В ТЕРМОДИНАМІЦІ БІОЛОГІЧНИХ ПРОЦЕСІВ
}

\author{
Municipal Higher Educational Establishment \\ "Zhytomyr Basic Pharmaceutical College” Zhytomyr Regional Council \\ MODERN MATHEMATICAL MODELS IN THERMODYNAMICS \\ OF BIOLOGICAL PROCESSES
}

V. A. Bolukh

\begin{abstract}
Мета роботи - продемонструвати шляхи формування математичної грамотності та науково-пізнавального інтересу у студентів на заняттях із дисципліни “Біофізика з фізичними методами аналізу”.

Основна частина. Стаття присвячена проблемі формування науково-пізнавального інтересу у студентів на заняттях з біофізики з фізичними методами аналізу. Приділено увагу ефективному використанню математичного моделювання у наукових дослідженнях з біології, хімії, медицини та фармації. На прикладі змістового модуля “Термодинаміка біологічних процесів” розглянуто сучасні математичні моделі опису реальних біологічних систем, зокрема проаналізована невирішена проблема математичного опису фазових переходів.

Висновок. Для підвищення науково-пізнавального інтересу студентів та покращення рівня розуміння навчального матеріалу з дисципліни “Біофізика з фізичними методами аналізу” слід на заняттях інформувати студентів про найновітніші відкриття в даній галузі знань, особливу увагу приділяти науковим розробкам сучасних наукових математичних та фізичних шкіл, адже це значною мірою є мотиваційним фактором вивчення дисципліни.
\end{abstract}

Ключові слова: термодинаміка біологічних процесів; формування науково-пізнавального інтересу.

The aim of the work - to demonstrate the ways of quantitative literacy formation and scientific and educational interest among students during the classes of Biophysics with Physical Methods of Analysis.

The main body. The article is devoted to the problem of scientific and educational interest formation among students during the classes of Biophysics with Physical Methods of Analysis. Attention is paid to the effective use of mathematical modeling in scientific researches in Biology, Chemistry, Medicine and Pharmacy. The article outlines the modern descriptive mathematical models of the real biological systems on the example of the content module under the title of Thermodynamics of Biological Processes. It has also been analyzed the unsolved problem of the mathematical description of phase transitions.

Conclusion. In order to raise the students' scientific and educational interest and improve their level of learning support materials' understanding in such discipline as Biophysics with Physical Methods of Analysis it is necessary to inform students about the most recent discoveries in this field of knowledge, to pay special attention to the scientific developments of modern scientific mathematical and physical schools, since this is in a considerable degree meant to be a motivating factor for discipline study.

Key words: thermodynamics of biological processes; formation of scientific and educational interest.

Вступ. “Біологічна фізика з фізичними методами аналізу” входить до переліку обов’язкових дисциплін для студентів медичних та фармацевтичних закладів вищої освіти спеціальності 226 “Фармація, промислова фармація”. Відповідно до освітньо-професійної програми, одним із програмних результатів навчання дисципліни є вміння студентів обирати оптимальні методи та способи розв’язування складних та спеціальних задач, відшукуючи шляхи вирішення проблемних ситуацій

(с) В. А. Болух у професійній діяльності. Кваліфіковане проведення біофармацевтичних та фармакологічних досліджень неможливе без грунтовних математичних та фізичних знань. Математичні моделі опису біофізичних процесів та явищ $є$ інструментом для змістовного розуміння студентами навчального матеріалу. Більшість фізичних, біологічних, хімічних, медичних процесів описується функціональною залежністю. Актуальність дослідження даної теми полягає в демонстрації глибокого зв’язку математики та фізики з природничими науками, викорис- 
тання студентами математичних знань та законів фізики в майбутній професійній діяльності.

Біологічні системи та відповідні їм математичні моделі молекулярного, кінетичного та популяційного рівня, динаміка та умови їх існування і взаємодії були об’єктами дослідження таких вчених, як А. Б. Рубін, Г. Ю. Різніченко, Ю. М. Романовський, Н. В. Степанова, Є. А. Леонтович, В. М. Глушков, Я. Г. Сінай, Г. М. Обатуров тощо.

В історичному аспекті свій внесок у розвиток біофізики започаткували М. В. Ломоносов (теорія кольорового бачення), Л. Гальвані (досліди 3 вивчення “Живої електрики”), Г. Гельмгольц (відкриття в галузі біологічної оптики), Д’Арсонваль (дослідження в області впливу змінних струмів на біологічні об’єкти). Серед видатних досягнень біофізики ХХ століття слід виділити розшифрування просторових структур білка Л. Полігом та подвійної спіралі ДНК Дж. Уотсоном та Ф. Кріком [1].

Проблему математичного моделювання на заняттях з біофізики порушено в роботах Н. Філоненко, А. Коченова, Г. Гнатюк [2], О. І. Олар, О. Ю. Микитюк, В. І. Федів, Д. І. Остафійчук [3]. Окремої уваги заслуговують дослідження В. Є. Мікшина, Є. Г. Алмазова [4]. Комп’ютерному моделюванню в курсах фізики та біофізики присвячена робота В. О. Тіманюк та інших [5].

Мета роботи - продемонструвати шляхи формування математичної грамотності та науково-пізнавального інтересу у студентів на заняттях із дисципліни “Біофізика з фізичними методами аналізу”.

Основна частина. Передумовою становлення математичного моделювання як методу наукового пізнання стали фундаментальні дослідження Г. В. Лейбніца - основоположника диференціального та інтегрального числення.

Математичне моделювання є найвищою формою моделювання. Воно сприяло розвитку науки й техніки індустріального суспільства, а з появою електронно-обчислювальних засобів обробки інформації привело до бурхливого розвитку сучасного - постіндустріального - суспільства. Метод моделювання є методом дослідження властивостей певного об'єкта (оригіналу) за допомогою вивчення властивостей іншого об’єкта (моделі), який є зручнішим для дослідження і знаходиться у певній відповідності до першого об’єкта (оригіналу). Моделювання - це побудова (або вибір) і вивчення такого об’єкта будь-якої природи (моделі), що здатний замінити собою досліджуваний об’єкт (оригінал) і вивчення якого дає нову інформацію про досліджуваний об’ єкт [6].

Вперше біологічні процеси були описані математичними моделями у 80-х роках XIX століття. Спроби опрацювання статистичних біомедичних даних англійським математиком та біологом Карлом Пірсоном у 1900 р. привели до бурхливого використання математичних методів і моделей у біології, хімії, медицині та фармації.

Безперечно, моделювання у медицині отримало самостійні функції і стає все більш необхідним у процесі проведення досліджень. Сьогодні моделювання в медицині є тим засобом, який дозволяє встановити глибокі і складні взаємозв'язки між теорією та експериментом. За останні сто років експериментальні методи в медицині почали наштовхуватися на цілий ряд обмежень і виявилося, що проведення деяких досліджень неможливе без моделювання. Це викликано такими факторами:

- втручання в біологічні системи може призводити до неможливості встановлення причин змін, що виникають при цьому;

- деякі теоретично обгрунтовані експерименти неможливо здійснити внаслідок недостатнього рівня розвитку експериментальної техніки;

- ряд експериментів, які необхідно проводити на людях, слід відхиляти з морально-етичних та правових питань [3].

Використання математичних методів та автоматизованих комп'ютерних систем у медицині та фармації суттєво розширило можливості діагностики та терапії захворювань, здійснення розробок методик контролю якості лікарських засобів, фармацевтичних субстанцій, лікарської рослинної сировини і допоміжних речовин із використанням фізичних, фізико-хімічних та хімічних методів контролю.

Зрозуміло, що не для всіх біологічних процесів можливо створити адекватні математичні моделі та надати математичний опис, оскільки біологічні об’єкти, як правило, є дуже складними, а на процеси, що перебігають у них, впливає багато факторів, які тим чи іншим чином пов'язані між собою. При застосуванні законів термодинаміки, електродинаміки, квантової та класичної механіки для опису рівноважних процесів або близьких до них процесів у біологічних об’єктах можна створити спрощені моделі, які дозволять отримати результати, що корелюють з експериментальними. Для створення більш наближених до реалії моделей слід враховувати, що біологічні процеси та системи є відкриті та стаціонарні, тому для їх опису слід використовувати моделі для нерівноважних процесів. 
При моделюванні процесів, що проходять у живих тканинах, у більшості випадків використовують диференціальні рівняння або навіть системи [2].

Опис реальних біологічних систем за допомогою математичних методів та моделей дозволяє розширити уявлення студента про об’єкт дослідження, вивчити поведінку об’єкта дослідження при зміні значень параметрів, якими описуються процеси, що відбуваються в даному об’єкті; зробити детальний аналіз та провести прогнозування зміни перебігу процесу за тих чи інших обставин тощо. Створення математичної моделі для реальної біологічної системи неможливе без формалізації процесів, що в ній перебігають, у вигляді системи математичних співвідношень та введення спеціальних параметрів системи.

На заняттях з біологічної фізики з фізичними методами аналізу студенти знайомляться 3 класичними математичними моделями опису реальних біологічних систем, такими, як модель динаміки розмноження, модель динаміки епідемії, фармакокінетичними моделями тощо. Доцільно також з метою розширення наукового світогляду студентів до їх уваги пропонувати сучасні дослідження з біофізики, знайомити їх з найновітнішими відкриттями.

3 огляду на вищенаведене, варто продемонструвати на прикладі змістового модуля “Термодинаміка біологічних процесів” доцільність ознайомлення студентів із сучасними математичними моделями опису реальних біологічних систем. При цьому особливу увагу слід звернути на сучасні дослідження українських вчених.

Термін “термодинаміка” ввів у класичну фізику у 1854 р. В. Томсон. Термодинаміка вивчає термодинамічні системи - сукупність матеріальних тіл, які перебувають у взаємодії з навколишнім середовищем і можуть обмінюватися з ним енергією і речовиною. Всі живі організми являють собою складні термодинамічні системи. Процеси обміну і перетворення енергії у системі пов'язані і супроводжуються змінами термодинамічних параметрів. Ці процеси прийнято називати термодинамічними процесами. Термодинамічні параметри - це фізичні величини, зміна яких приводить до зміни стану системи.

Фундаментальним поняттям термодинаміки $є$ рівноважний стан системи, при якому термодинамічні параметри мають однакові значення у всіх точках системи і не можуть самовільно змінюватися з часом. Для біологічної системи рівноважний стан $€$ неможливим. Тому у термодинаміці біоло- гічних систем основним є поняття стаціонарного стану системи, при якому термодинамічні параметри залишаються сталими, але можуть мати різні значення у різних точках системи (наприклад, температура у різних частинах людського організму $€$ різною). У біологічних системах існують і постійно підтримуються градієнти термодинамічних параметрів.

Всі реакції, які відбуваються у біологічних системах, супроводжуються виділенням чи поглинанням енергії. Між термодинамічною системою та оточуючим середовищем постійно відбувається обмін енергією у вигляді теплоти та роботи. Співвідношення між внутрішньою енергією, теплотою та роботою встановлює перший закон термодинаміки.

Відповідно до загального закону природи, всі системи, які складаються з великої кількості частинок, завжди прагнуть до найбільш невпорядкованого стану. Для оцінки ступеня невпорядкованості системи вводять спеціальну термодинамічну функцію - ентропію. Критерій Клаузіуса стверджує, що система прагне досягти кінцевого рівноважного стану при максимальній ентропії.

Проведення термодинамічних розрахунків неможливе без використання термодинамічних потенціалів. Термодинамічний потенціал - це функція стану, його зміни в деякому процесі, що відбувається при постійних значеннях певної пари термодинамічних параметрів, і дорівнює корисній роботі, що виконує система.

При сталих об'ємі і температурі корисна робота буде здійснюватися за рахунок термодинамічного потенціалу, що називається вільною енергію Гельмгольца, а при сталих тиску і температурі - за рахунок вільної енергії Гіббса. Враховуючи критерій Клаузіуса, ці термодинамічні потенціали у біологічних системах прямуватимуть до мінімальних значень. Тому критерієм здатності системи здійснювати певне термодинамічне перетворення $€$ знак зміни вільної енергії Гіббса або Гельмгольца.

Актуальним питанням залишається математичний опис фазових переходів, а саме доведення існування фазових переходів для стандартних взаємодій типу Ленарда - Джонса. Відомо, що з хімічної точки зору фаза визначається як фізично і хімічно однорідний стан речовини, що має визначену сукупність властивостей. Після переходу в іншу фазу речовина залишається однорідною, але набуває інших властивостей. Такий перехід має назву фазового. 3 фізичної точки зору, фазовий перехід - це трансформація внутрішньої структури речовини, 
при якій відбувається різкий стрибок певної фізичної характеристики системи, викликаний малою зміною іншої характеристики.

У 1993 р. австрійсько-нідерландський фізик-теоретик П. Еренфест ввів класифікацію фазових переходів, згідно з якою розрізняють фазові переходи першого та другого роду. До фазових переходів першого роду відносять переходи, за яких стрибком змінюються величини, що визначаються як перші похідні термодинамічного потенціалу за температурою та тиском. При фазових переходах другого роду неперервними залишаються термодинамічний потенціал та його перші похідні за температурою та тиском, але стрибком змінюються другі похідні, через які виражають теплоємність, коефіцієнт теплового розширення та стиску. Основи теорії фазових переходів другого роду були створені Л. Ландау у 1937 р.

Проблема фазових переходів ще й досі залишається актуальною, навіть незважаючи на цілу низку опублікованих досліджень, що стосуються даного питання. Так, незалежно один від одного Р. Л. Добрушин та Р. Гріффітс довели існування фазового переходу першого роду для моделі Ізінга. Існує також приклад одновимірної неперервної системи (так звана модель Катца), в якій також виявлено фазовий перехід першого роду.

Проте для звичайних неперервних систем взаємодіючих частинок, які описують реальні біологічні системи, узагальнити розроблені вченими методи ще й досі не вдалося. Деякі аналогічні результати були отримані для неперервних систем в області граничних значень достатньо малих значень параметрів оберненої температури та хімічної активності. Задача зводилася до розгляду штучних моделей - моделі Уідома - Роулінсона, при цьому методи дослідження базувалися на теорії гратчастих газів.

Доцільно ознайомити студентів із вагомим внеском сучасних українських вчених у дослідження даного питання.

У 2012 р. головний науковий співробітник відділу математичної фізики Інституту математики НАН України О. Л. Ребенко ввів нову неперервну модель - комірковий газ [7].

Модель коміркового газу є перехідною між моделями гратчастих газів і неперервними системами статистичної механіки. В рамках введеної моделі за порівняно невеликий проміжок часу вже вдалося отримати ряд важливих результатів. Модель коміркового газу апроксимує неперервну систему точкового газу з наперед заданою точністю. Для розрахунків основних термодинамічних потенціалів нескінченних систем достатньо досліджувати ці функції тільки на конфігураціях, у яких в комірку (уявний гіперкубик з ребром розміру $a$, яке можна вибрати як завгодно малим) потрапляє не більше однієї частинки. Дослідження такої моделі $є$ актуальними для вирішення відкритої проблеми опису фазових переходів і дослідження критичних явищ неперервних систем класичної статистичної механіки.

В роботах О. Л. Ребенка спільно з його учнями (М. В. Тертичним, С. М. Петренком та В. А. Болух) було показано, що:

- для посилено надстійких потенціалів тиск апроксимованої системи прямує до тиску досліджуваної неперервної системи, якщо параметр розбиття спрямувати до нуля (в ролі параметра виступає розмір ребра комірки $a$ ) у так званій термодинамічній границі для будь-яких додатних значень оберненої температури та хімічної активності. Подібний результат було узагальнено для системи з багаточастинковою взаємодією;

- доведено, що апроксимована вільна енергія Гельмгольца моделі коміркового газу з будь-яким ступенем точності наближається до відповідної вільної енергї̈ неперервної системи.

Питання математичного опису фазових переходів на сьогодні залишається відкритим. Тому провідні науковці світу ще й досі зацікавлені в розв'язанні цієї проблеми.

Після ознайомлення студентів з сучасними відкриттями в кінці кожної теми варто пропонувати їм спробувати власні сили на теренах наукової праці, окресливши теми науково-дослідних робіт. Найцікавіші дослідження студентів слід презентувати у вигляді тез студентських конференцій або наукової статті у співавторстві з науковим керівником у провідних фахових виданнях.

Висновок. Отже, для підвищення науково-дослідного інтересу студентів та покращення рівня розуміння навчального матеріалу з дисципліни “Біофізика з фізичними методами аналізу” слід на заняттях інформувати студентів про найновітніші відкриття в даній галузі знань, особливу увагу приділяти науковим розробкам сучасних наукових математичних та фізичних шкіл, адже це значною мірою є мотиваційним фактором вивчення дисципліни. 


\section{Список літератури}

1. Личковський Е. І. Фізичні методи аналізу та метрологія : підручник / Е. І. Личковський, В. О. Тіманюк, О. В. Чалий. - Вінниця : Нова Книга, 2014. - 464 с.

2. Філоненко Н. Математичне моделювання в фізиці / Н. Філоненко, А. Коченов, І. Гнатюк // Наукові записки. - Вип. 10. - Серія: Проблеми методики фізико-математичної і технологічної освіти. Частина 2. - Кіровоград : РВВ КДПУ ім. В. Винниченка, 2016. - С. 89-92.

3. Методи математичного моделювання як важливий розділ знань для студентів медичних та фармацевтичних спеціальностей / О. І. Олар, О. Ю. Микитюк, В. І. Федів, Д. І. Остафійчук // Наукова промисловість Європейського континенту - 2013 : зб. матеріалів IX Міжнар. наук.-практ. конф. - Прага : Publishing House "Education and Science”, 2013. - Режим доступу : https://core.ac.uk/ download/pdf/144954141.pdf.

\section{References}

1. Lychkovskyi, E.I., Timaniuk, V.O., \& Chalyi, O.V. (2014). Fizychni metody analizu ta metrolohiia [Physical methods of analysis and metrology]. Vinnytsia: Nova Knyha [in Ukrainian].

2. Filonenko, N., Kochenov, A., \& Hnatiuk, I. (2016). Matematychne modeliuvannia v fizytsi [Mathematical modeling in physics]. Naukovi zapysky - Scientific Notes. Kirovohrad: RVV KDPU im. V. Vynnychenka, 10 (2), 8992 [in Ukrainian].

3. Olar, O.I., Mykytiuk, O.Yu., Fediv, V.I., \& Ostafiichuk, D.I. (2013). Metody matematychnoho modeliuvannia yak vazhlyvyi rozdil znan dlia studentiv medychnykh ta farmatsevtychnykh spetsialnostei [Methods of mathematical modeling as an important part of knowledge for students of medical and pharmaceutical specialties]. $M a-$ terialy IX Mizhnarodnoi naukovo-praktychnoi konferentsii "Naukova promyslovist Yevropeiskoho kontynentu 2013”- Proceedings of the IX International Scientific and Practical Conference "Scientific Industry of the European Continent 2013”. Praha: Publishing House "Education and Science”. Retrieved from: https://core.ac.uk/download/ pdf/144954141.pdf [in Ukrainian].
4. Микшина В. С. Математические модели уравнений в здравоохранении / В. С. Микшина, Е. Г. Алмазова // Математическое моделирование. - 2009. - Т. 21, № 4. C. 111-121.

5. Компьютерное моделирование в курсах физики и биофизики / В. О. Тиманюк, М. Г. Кокодий, Ю. М. Пенкин, А. А. Рыжов ; МЗ Украины, Нац. фармац. ун-т, Запорож. гос. мед. ун-т. - Запорожье : ЗГМУ, 2010. - 520 с. 6. Станжицький О. М. Основи математичного моделювання : навч. посіб. / О. М. Станжицький, Є. Ю. Таран, Л. Д. Гординський. - К. : Видавничо-поліграфічний центр “Київський університет”, 2006. - 96 с.

7. Rebenko O. L. Cell gas model of classical statistical systems / O. L. Rebenko // Rewiew in Math. Phys. - 2012. Vol. 25, No. 4. - P. 28.

4. Mikshina, V.S., \& Almazova, E.G. (2009). Matematicheskie modeli uravneniy v zdravoohranenii [Mathematical models of healthcare service equations]. Matematicheskoe modelirovanie - Mathematical Modelling, 21 (4), 111-121 [in Russian].

5. Timanyuk, V.O., Kokodiy, M.G., Penkin, Yu.M., \& Ryizhov, A.A. (2010). Kompyuternoe modelirovanie $v$ kursakh fiziki i biofiziki [Computer simulation in physics and biophysics courses]. MZ Ukrainy, Nats. farmats. un-t, Zaporozh. gos. med. un-t. - Zaporozhye: ZGMU [in Russian].

6. Stanzhytskyi, O.M., Taran, Ye.Iu., \& Hordynskyi, L.D. (2006). Osnovy matematychnoho modeliuvannia [Fundamentals of mathematical modeling]. Navchalnyi posibnyk [Fundamentals of mathematical modeling: Teaching. manual]. Kyiv: Vydavnycho-polihrafichnyi tsentr "Kyivskyi universytet” [in Ukrainian].

7. Rebenko, O.L. (2012). Cell gas model of classical statistical systems. Rewiew in Math. Phys., 25, 4 (13330006), 28. 